\title{
Microfluidic Technologies for Yeast Replicative Lifespan Studies
}

\section{Kenneth L Chen ${ }^{1,2,3}$, Matthew M Crane ${ }^{1}$, Matt Kaeberlein ${ }^{1 *}$}

${ }^{1}$ Department of Pathology, University of Washington Seattle, Washington, USA

${ }^{2}$ Department of Genome Sciences, University of Washington, Seattle, Washington, USA

${ }^{3}$ Medical Scientist Training Program, University of Washington, Seattle, Washington USA

*corresponding author email: kaeber@uw.edu

ABSTRACT. The budding yeast Saccharomyces cerevisiae has been used as a model organism for the study of aging for over 50 years. In this time, the canonical aging experiment-replicative lifespan analysis by manual microdissection - has remained essentially unchanged. Recently, microfluidic technologies have been developed that may be able to substitute for this time- and labor-intensive procedure. These technologies also allow cell physiology to be observed throughout the entire lifetime. Here, we review these devices, novel observations they have made possible, and some of the current system limitations.

\section{Keywords}

yeast, microfluidics, microscopy, replicative aging, microdissection, lifespan 


\section{Introduction}

Although budding yeast colonies can be propagated indefinitely, in 1959, Mortimer and Johnson reported that individual yeast cells are not immortal. S. cerevisiae cells reproduce clonally but asymmetrically, with a smaller daughter cell budding from its larger mother ${ }^{1}$. Mortimer and Johnson closely monitored individual mother cells grown on an agar pad and periodically used a micromanipulator to manually remove mature daughter buds. This removal of daughter cells is necessary because a single mother cell becomes indiscernible from its exponentially dividing progeny after only a handful of division cycles. In this seminal study, they reported that an individual mother cell can divide only a finite number of times-its replicative lifespan.

Since then, multiple conserved longevity pathways have been discovered in the budding yeast ${ }^{2}$. With a short generation time, genetic tractability, and minimal husbandry costs, the budding yeast has become a premier model organism for aging research ${ }^{3}$. Mortimer and Johnson's microdissection technique, developed over fifty years ago, remains the bread-and-butter yeast aging assay ${ }^{4}$. Unfortunately, it is also time and labor intensive. As a consequence, many labs forgo replicative lifespan studies, and, even among those that perform them, sample sizes are often too small for rigorous statistical confidence in published results. For example, the only genome-wide analysis of replicative lifespan performed to date utilized an iterative strategy involving lifespan analysis of only 5 cells per deletion strain ${ }^{5,6}$. Thus, in many ways, the standard replicative lifespan assay has become a rate-limiting step in the progress of yeast aging research.

Recently, a number of groups ${ }^{7-14}$ have developed microfluidic technologies to address this problem (Table 1). Microfluidic devices refer to a diverse class of objects featuring sub-millimeter chambers and channels. At this scale, fluids have interesting mechanical properties-such as laminar flow-which allow researchers to precisely manipulate tiny volumes of liquid for applications including bioassay integration, high throughput screening, and chemical synthesis among many others ${ }^{15,16}$. Devices constructed from polydimethylsiloxane (PDMS) - a clear, gas-permeable, and biocompatible elastopolymer-have proven particularly useful for cell biology. Tiny cell culture chambers with precisely controlled cellular microenvironments can be created by sealing PMDS blocks with micron-sized surface features onto glass cover slips. Although an exhaustive discussion of the fabrication of such devices and their applications is beyond the scope of this article, we refer the interested reader to several recent reviews $^{17-20}$.

A wide variety of microfluidic devices, including a commercial platform, have been developed for yeast culture and investigation ${ }^{8-14,21-30}$. Most, however, are only suitable for experiments lasting a few hours or less ${ }^{21-27}$. Though earlier attempts were made to apply microfluidics to yeast aging research ${ }^{7,30,31}$, the first device to successfully demonstrate the ability to perform a replicative lifespan analysis was published in $2012^{8}$. Since then, six additional microfluidic designs with lifespan analysis capabilities have been developed ${ }^{9-14}$. The devices developed for yeast aging feature clever geometrical structures to mechanically trap mother cells. These structures exploit the size difference between mother cells and newborn daughter cells or the budding patterns of mother cells, generally allowing fluid flow to selectively remove mature daughters. The effective removal of undesired cells is crucial to prevent the device from becoming overgrown with multiplying progeny. When coupled with time-lapse microscopy, these devices allow both measurement of replicative lifespans and observation of physiological changes as the trapped cells age. A typical lifespan experiment using a microfluidic device at standard $30^{\circ} \mathrm{C}$ 
conditions lasts $2-5$ days. In contrast, microdissection experiments performed using standard methods, where cells are incubated at $4^{\circ} \mathrm{C}$ overnight, can last up to 3 weeks. This mini-review will discuss these seven microfluidic devices for the whole-lifespan trapping and monitoring of budding yeast cells.

\section{Device Designs}

\subsection{Chemical and Mechanical trapping}

The first microfluidic device developed to perform a replicative lifespan experiment was published by Xie and colleagues in $2012^{8}$. This device uses both mechanical constraints and biotin-avidin affinity (Figure 1A). In this device, the height of the trapping chamber is $4 \mu \mathrm{m}$, approximately the diameter of a yeast cell. Additionally, the glass surface is functionalized with biotinylated bovine serum albumin followed by neutravidin. Prior to loading into the device, cells are labeled with biotin. Because daughter cell walls are generated anew, only the mother cells retain this surface mark. After loading, mother cells are immobilized both mechanically-squeezed between the PDMS ceiling and the glass floor of the chamber-and chemically-glued to the glass floor by the interaction of the cell's biotin and the device's avidin. Fluid flow preferentially removes the smaller, biotin-free daughter cells. Multiple trapping chambers are arrayed like rungs in a ladder between two taller main flow channels, which allows for chambers exposed to a range of flow speeds. Yeast replicative lifespan curves were successfully generated using this device; however, those lifespans were shorter (see Table 2) than the results seen from microdissection experiments on agar plates ${ }^{8}$.

\subsection{Vertical mechanical trapping by pensile columns/micropads}

Later in 2012, two groups published very similar device designs using purely geometric measures to selectively trap mother cells ${ }^{9,10}$. In these designs, the trapping chamber does not have a uniform height. "Micropads" (30 by $15 \mu \mathrm{m}$, Lee et al.) or "pensile columns" (40 by $40 \mu \mathrm{m}$, Zhang et al.) descend from the PDMS ceiling to create areas where the floor to ceiling distance is only 4-5 $\mu \mathrm{m}$ (Figure 1B). Between the micropads/columns, the trapping chamber is much taller (15 $\mu \mathrm{m}$ for Lee et al., unspecified for Zhang et al.) Cells are loaded at high pressure, pushing the column areas upwards temporarily and allowing cells to flow underneath. When this pressure is released, the cells are trapped, sandwiched under the micropad above. Again, mother cells are preferentially retained over the smaller daughters because of the size difference. Moreover, the limited area of the micropad/column prevents overgrowth, as progeny that grow into the non-micropad areas are no longer vertically constrained and more easily washed out. However, Lee et al. reported that over $70 \%$ of cells were lost before the end of their experiments. Retention data was not reported by Zhang et al.

\subsection{Trapping in elongated cavities}

The CLiC (Cell Loaded into a Cavity) device features "trapping areas" (90 by $40 \mu \mathrm{m}, 3.3 \mu \mathrm{m}$ height) arranged in a grid and separated by media flush channels $(40 \mu \mathrm{m} \text { height })^{11}$. Each trapping area features two elongated "cavities" or dead-end hallways that run off of the main trapping area (6 or 10 by $32 \mu \mathrm{m}$ ) (Figure 1C). This design requires a significantly larger footprint per trapped mother cell than the other devices. This may become an issue in experiments that require a large number of cells (e.g. investigating rare events) when the speed of the microscope components becomes a limiting factor. Cells are loaded through the media flush channels such that a handful are caught within each trapping area. Subsequent 
cell division results in a confluent monolayer of cells in the trapping area that eventually deposits a new virgin cell (never having previously produced a daughter cell) at the dead-end tip of the elongated cavity. This method has the advantage that cells are guaranteed to be virgin at the beginning of the lifespan experiment, while the previous three designs are unable to control this ${ }^{11}$. In a log-phase culture, one would expect about half of the cells to be virgin daughters and less than $1 / 16$ of the cells to have budded more than three times. Staining of bud scars showed that the average age of a trapped cell under a pensile column in Zhang et al. is less than two divisions at the start of an experiment ${ }^{10}$.

The CLiC device depends on the unipolar axial budding pattern of haploid yeast cells in the BY strain background ${ }^{11}$. It is worth noting that this device, along with all devices described in this review have only been demonstrated for lifespan analyses of haploid cells and may be unsuitable for larger diploid cells, as discussed further below. If a cell at the dead-end tip of the cavity buds towards the exit, it will continue to bud in the same direction and tend to remain trapped in the cavity for its entire replicative lifespan. The limited width of the cavity ensures that daughters and further progeny are continuously pushed out of the cavity. Although cells can rotate and polarity switches occur occasionally, the authors reported retention of $\sim 65 \%$ of trapped mother cells for their entire replicative lifespans ${ }^{11}$.

\subsection{Trapping between two columns}

The ALCATRAS (A Long-term Culturing and TRApping System) device utilizes traps each composed of two floor-to-ceiling columns arranged with a " $\backslash /$ " shaped footprint (Figure 1D). When a cell suspension is flowed into the device, individual cells are caught between the two columns. Continuous, unidirectional fluid flow keeps each mother cell immobilized against the columns. The limited height of the device chamber discourages vertical stacking of cells. Like the designs described above, this device exploits the size difference between mother and daughter cells. Daughter buds are forced downstream through the gap between the two columns, detaching when mature. Buds that emerge upstream are similarly removed by fluid flow upon maturity, and the authors reported whole-lifespan retention of $\sim 40-60 \%$ of trapped mother cells. The ALCATRAS device also does not guarantee that mothers begin the experiment as virgins. However, unlike all the previously described devices, which have non-uniform internal heights, the mold for this device requires features of only a single height.

The HYAA-Chip (High-throughput Yeast Aging Analysis) follows essentially the same principle as the ALCATRAS device, sharing the advantages of single-layer fabrication and small trap footprint. However, the cross-section of the floor-to-ceiling columns is different, as is the spacing between columns in a single trap and between traps (Figure 1E). The general layout and dimensions of the device are also different, and it supports up to 16 strains in parallel. These changes resulted in reports of $>90 \%$ retention of wild-type mother cells for their entire lifespans ${ }^{13}$. This device and trapping structure has been validated on a number of both long- and short-lived mutants (Table 1). The trapping mechanism used in both of these papers allows a higher density of cells to be imaged within a single field of view when compared with the previous designs.

\subsection{Trapping in a three-column jail}

The Yeast Replicator device also uses vertical floor-to-ceiling columns to trap individual cells, modifying an earlier three-column "jail" design ${ }^{14,30}$ (Figure 1F). The three columns, arrayed at the vertices of an equilateral triangle, create a fully constrained trapping area for a single cell. When cells are loaded into the device, they are first caught between two columns outside the jail. These temporarily immobilized 
cells can then bud into the central trapping area. When mature, the buds become the trapped mother cells. Like the CLiC device, the Yeast Replicator guarantees that trapped cells start in the device as virgins. Daughter buds of these trapped cells emerge in between the three columns of the jail and are washed away when mature. Retention rates were not reported by the authors ${ }^{14}$.

\section{Discoveries}

Coupled with time-lapse microscopy, these devices allow researchers to more easily collect replicative lifespan data. Moreover, when combined with fluorescently-labeled proteins or dyes, researchers can track changes in cell physiology (e.g. organelle structure or function ${ }^{9,11,32,33}$, protein level or localization $12,13,34,35$, promoter activity ${ }^{8,10,14}$, daughter-cell birth characteristics ${ }^{36,37}$ ) across the aging process. Importantly, these measures can be associated at single-cell resolution with lifespan or other ageassociated changes (e.g. cell cycle duration). A number of interesting observations have followed. For example, researchers found that delays in nuclear segregation during cytokinesis occur rarely during a cell's lifetime but increase dramatically in frequency after division speeds slow with age ${ }^{32}$. Researchers also correlated heterogeneity in end-state cell morphology, which had been previously reported by microdissection studies ${ }^{38,39}$, with molecular properties of those cells. Cells trapped under a PDMS column that die in a round (as opposed to elongated) morphology are shorter-lived, display more pronounced measures of mitochondrial dysfunction, and have higher Hsp104 promoter activity at death ${ }^{9,10}$. This suggests that each yeast cell may experience one of multiple modes of cellular death. Interestingly, another report using paired-column traps correlated lifespan with the morphology of the attached daughter bud at cell death (round, elongated, or no bud) but made no mention of elongated mothers ${ }^{13}$. This suggests that the geometry of the trapping structure may affect trends in aged cell morphology.

Building on the widely mentioned observation that cell cycle durations increase dramatically during the last few cell divisions ${ }^{8-11,14,40}$, Xie et al. found that mutants defective in telomerase function display stochastic episodes of cell-cycle lengthening in young cells. These strains are short-lived, display aged mitochondrial morphology, and activate more frequent bursts of DNA damage response throughout life. Interestingly, lifespan shortening is unrelated to telomere length ${ }^{37}$. Xu et al. made similar observations when tracking cellular lineages instead of mother cells. They observed a subpopulation of lineages that experienced stochastically (but not progressively) elongated cell divisions, linking this behavior to Pol32 DNA damage repair activity ${ }^{41}$.

Mitochondrial membrane potential has previously been implicated as a biomarker or mediator of agerelated cellular pathology ${ }^{42-46}$. By tracking the mitochondrial membrane potential in individual cells across the aging process, Fehrmann et al. found that the instantaneous risk of losing mitochondrial membrane potential did not increase with age. Moreover, they reported that the cells who eventually lost mitochondrial membrane potential were not significantly shorter-lived than those who maintained high mitochondrial potential for their entire lifespans ${ }^{11}$. These types of observations are wholly dependent on the ability to follow single cells and observe their physiological states through the entire aging process. 


\section{Considerations}

Because lingering progeny cells will divide and proliferate exponentially, microfluidic lifespan devices must effectively clear the vast majority of daughter cells to keep the device from becoming clogged with cells. Thus, a very delicate balance must be struck between retention of mother cells and removal of unwanted progeny. The key innovation of most of these devices is a geometry that exploits the size difference between mother and daughter cells to immobilize aging mothers and wash away new daughter cells. And as such, all designs are very sensitive to the size of the mother. All devices mentioned in this review have focused on haploid cells, and although the size difference and altered budding pattern of diploids doesn't ensure failure, so far none of these devices have been tested on diploid cells. While this may not be a severe limitation to the utility of such devices, it is clear that ploidy can impact replicative lifespan in yeast (for example BY4743 diploids are longer-lived than the corresponding haploid strains) ${ }^{47}$, and aging studies in nearly every other model system are performed in diploid organisms.

Moreover, even within haploids, this balance is complicated by several factors. Mother and daughter cells are nearly identical in size during the first division or two. The device needs to be able to trap these small mother cells effectively at the beginning of the experiment. However, over the course of their lifespans, old mother cells can grow to be multiple times the size of young mother cells. The trapping geometry needs to accommodate these much larger cells as well, as excessive pressure on cells can induce stress responses and may reduce lifespan ${ }^{9,14}$. Daughters of old mother cells are also larger ${ }^{48}$, and it is unknown whether pressure on growing buds (constrained between two columns in some designs) can affect the aging process. Additionally, a large daughter bud can dislodge its mother from a trap, and multiple buds sometimes remain attached to the mother cell in a clustered arrangement, further complicating the designs. Judgment of the success of many of the published devices in overcoming these obstacles is difficult due to the lack of raw data available (i.e. time-lapse videos showing the whole device or an entire field of view). Indeed, the devices mentioned in this review have widely varying trends for mother cell retention through time (see Table 1). Lastly, because the devices feature differences in general layout as well as in trap shape, the same trap design may perform differently depending on the overall device layout.

An experiment where most of the cells are lost before senescence is not necessarily a failure. Statistical right-censoring to utilize partial lifespan data (i.e. a mother cell that is retained for several divisions but washed out before senescence) is routinely used in survival analysis ${ }^{49}$. However, the reasoning that undergirds this method assumes that cells disappearing before senescence are not systematically different than those trapped for their entire lifespans. The fact that these devices exploit cellular size or budding characteristics to trap mother cells is a strong indicator that this requirement may not be upheld. Moreover, as cells continue to grow in volume over their entire lifespans, published work has suggested that cell size may be a biomarker of remaining lifespan ${ }^{13,50}$. Thus genetic or environmental interventions that affect lifespan through pathways that also affect cellular budding patterns or geometry may not be suitable for study in some devices. This may be a particularly important limitation, given that many genetic and environmental interventions that extend lifespan also affect mother cell size ${ }^{50,51}$.

Thus far, studies have not attempted to demonstrate robustness of lifespan results to microfluidicspecific experimental conditions such as fluid speed, culture growth phase, or pre-loading treatments 
such as sonication or centrifugation. Some of the published devices have reported lifespans both for wild-type cells, and a small number of short- and long-lived strains that are comparable to those measured by microdissection ${ }^{8-10,13,14}$. However, a major limitation of the current literature in this area is that no studies have assessed the ability of any microfluidic device to recapitulate the reported longevity effects of a large number of longevity-altering interventions. In one case, Huberts et al. reported that the longevity-promoting effect of caloric restriction is not seen in their microfluidic design. Their observations were accompanied by an interesting meta-analysis showing that studies showing the protective effects of dietary restriction in yeast generally reported control populations that were shorter-lived than the norm ${ }^{52}$. Later, Jo et al. found that dietary restriction does increase longevity in cells aged in their device, noting that the conclusions of Huberts et al. were drawn from lifespan experiments in which $\sim 85 \%$ of initial population was censored ${ }^{13}$.

Going forward, it will be important to establish which microfluidic device designs, and under what experimental conditions, most closely recapitulate the results obtained using the "gold standard" microdissection assay across a spectrum of genetic and environmental conditions. This is particularly true in those cases where the yeast replicative aging model has been found to recapitulate the effects of analogous interventions in multicellular eukaryotes, such as $C$. elegans ${ }^{53,54}$. Key pathways that should be explored in detail include the ability of yeast cells to show lifespan extension from dietary restriction (both glucose and other nutrients) and the response to conserved genetic modifiers of aging such as sirtuins and the target of rapamycin (TOR).

\section{Dissemination}

In addition to concerns about device performance, adoption of microfluidic technologies can be difficult for labs without previous microfluidics expertise. While the scientists who develop and use these devices are generally happy to share blueprints of the photomask (which can then be purchased from a number of sources), in order to manufacture the device molds using the photomasks, a nanofabrication facility is typically required. In addition, there are often significant knowledge and financial barriers for labs to set up and troubleshoot the microfluidic system even after obtaining a working device. For example, use of these devices has been largely limited to laboratories with access to expensive motorized microscopes. These microscopes allow researchers to parallelize experiments, capturing lifespans of multiple strains at once (through device design or the use of multiple devices at once). Most yeast labs do not have such a microscope available that can be dedicated solely to yeast lifespan experiments and, because experiments require continuous monitoring for upwards of 2 days, core facility rates for such a microscope can also be unaffordable.

In order to help overcome this barrier, we have set out to develop a lower cost microfluidic platform for basic analysis of replicative lifespan and cell morphological features during aging. We are currently optimizing a system that costs about $\$ 2,500$ to build from scratch. This includes the microscope, camera, syringe pump, and additional necessary accessories to perform microfluidic aging experiments. We anticipate publication and dissemination of this system within the next year, and we hope this will facilitate broader adoption of microfluidic technologies within the yeast geroscience community. 


\section{Conclusion and Future}

The reviewed microfluidic devices offer alternatives to the traditional method of microdissection for collecting replicative lifespan data. Moreover, these devices are currently the only validated methods for collecting in situ, single-cell data on aging physiology across an entire lifespan. Adoption of these methods can be challenging but has begun to spread beyond the labs that developed each design, and they are poised to become an essential tool for the study of replicative aging in yeast. The impact of different device designs and experimental conditions on robustness and reproducibility is currently unknown, however, and this should be a major focus of laboratories designing and utilizing microfluidic systems for yeast aging in the future.

Acknowledgements - This work was supported the UW Nathan Shock Center of Excellence in the Basic Biology of Aging (NIH Grant (NIH P30AG013280). MMC is supported by NIH Training Grant T32AG000057. Research by KLC was conducted with Government support under contract FA9550-11-C0028 and awarded by the Department of Defense, Air Force Office of Scientific Research, National Defense Science and Engineering Graduate (NDSEG) Fellowship, 32 CFR 168a. 


\section{REFERENCES:}

1 Mortimer, R. K. \& Johnston, J. R. Life Span of Individual Yeast Cells. Nature 183, 1751-1752, doi:10.1038/1831751a0 (1959).

2 Wasko, B. M. \& Kaeberlein, M. Yeast replicative aging: a paradigm for defining conserved longevity interventions. FEMS yeast research 14, 148-159, doi:10.1111/1567-1364.12104 (2014).

3 Denoth Lippuner, A., Julou, T. \& Barral, Y. Budding yeast as a model organism to study the effects of age. FEMS microbiology reviews 38, 300-325, doi:10.1111/1574-6976.12060 (2014).

$4 \quad$ Steffen, K. K., Kennedy, B. K. \& Kaeberlein, M. Measuring Replicative Life Span in the Budding Yeast. Journal of visualized experiments : JoVE, doi:10.3791/1209 (2009).

$5 \quad$ Kaeberlein, M. \& Kennedy, B. K. Large-scale identification in yeast of conserved ageing genes. Mech Ageing Dev 126, 17-21, doi:10.1016/j.mad.2004.09.013 (2005).

6 McCormick, M. A. et al. A Comprehensive Analysis of Replicative Lifespan in 4,698 Single-Gene Deletion Strains Uncovers Conserved Mechanisms of Aging. Cell Metab 22, 895-906, doi:10.1016/j.cmet.2015.09.008 (2015).

7 Koschwanez, J. et al. in IEEE International Conference on Automation Science and Engineering, 2005. 13-18.

8 Xie, Z. et al. Molecular phenotyping of aging in single yeast cells using a novel microfluidic device: Molecular phenotyping of aging. Aging Cell 11, 599-606, doi:10.1111/j.1474-9726.2012.00821.x (2012).

9 Lee, S. S., Vizcarra, I. A., Huberts, D. H. E. W., Lee, L. P. \& Heinemann, M. Whole lifespan microscopic observation of budding yeast aging through a microfluidic dissection platform. Proceedings of the National Academy of Sciences 109, 4916-4920, doi:10.1073/pnas.1113505109 (2012).

10 Zhang, Y. et al. Single Cell Analysis of Yeast Replicative Aging Using a New Generation of Microfluidic Device. PloS one 7, e48275, doi:10.1371/journal.pone.0048275 (2012).

11 Fehrmann, S. et al. Aging Yeast Cells Undergo a Sharp Entry into Senescence Unrelated to the Loss of Mitochondrial Membrane Potential. Cell reports 5, 1589-1599, doi:10.1016/j.celrep.2013.11.013 (2013).

12 Crane, M. M., Clark, I. B. N., Bakker, E., Smith, S. \& Swain, P. S. A Microfluidic System for Studying Ageing and Dynamic Single-Cell Responses in Budding Yeast. PloS one 9, e100042, doi:10.1371/journal.pone.0100042 (2014).

13 Jo, M. C., Liu, W., Gu, L., Dang, W. \& Qin, L. High-throughput analysis of yeast replicative aging using a microfluidic system. Proceedings of the National Academy of Sciences 112, 9364-9369, doi:10.1073/pnas.1510328112 (2015).

14 Liu, P., Young, T. Z. \& Acar, M. Yeast Replicator: A High-Throughput Multiplexed Microfluidics Platform for Automated Measurements of Single-Cell Aging. Cell reports 13, 634-644, doi:10.1016/j.celrep.2015.09.012 (2015).

15 Elvira, K. S., Casadevall i Solvas, X., Wootton, R. C. \& deMello, A. J. The past, present and potential for microfluidic reactor technology in chemical synthesis. Nature chemistry 5, 905-915, doi:10.1038/nchem.1753 (2013).

16 Sackmann, E. K., Fulton, A. L. \& Beebe, D. J. The present and future role of microfluidics in biomedical research. Nature 507, 181-189, doi:10.1038/nature13118 (2014).

17 Xia, Y. \& Whitesides, G. M. Soft lithography. Annual review of materials science 28, 153-184 (1998).

18 Qin, D., Xia, Y. \& Whitesides, G. M. Soft lithography for micro-and nanoscale patterning. Nature protocols 5, 491-502 (2010). 
Weibel, D. B., DiLuzio, W. R. \& Whitesides, G. M. Microfabrication meets microbiology. Nature Reviews Microbiology 5, 209-218 (2007).

20 Sackmann, E. K., Fulton, A. L. \& Beebe, D. J. The present and future role of microfluidics in biomedical research. Nature 507, 181-189 (2014).

21 Hersen, P., McClean, M. N., Mahadevan, L. \& Ramanathan, S. Signal processing by the HOG MAP kinase pathway. Proceedings of the National Academy of Sciences of the United States of America 105, 7165-7170, doi:10.1073/pnas.0710770105 (2008).

22 Uhlendorf, J. et al. Long-term model predictive control of gene expression at the population and single-cell levels. Proceedings of the National Academy of Sciences 109, 14271-14276, doi:10.1073/pnas.1206810109 (2012).

23 Mettetal, J. T., Muzzey, D., Gómez-Uribe, C. \& Oudenaarden, A. v. The Frequency Dependence of Osmo-Adaptation in Saccharomyces cerevisiae. Science 319, 482-484, doi:10.1126/science.1151582 (2008).

24 Bennett, M. R. \& Hasty, J. Microfluidic devices for measuring gene network dynamics in single cells. Nature Reviews Genetics 10, 628-638, doi:10.1038/nrg2625 (2009).

25 Bennett, M. R. et al. Metabolic gene regulation in a dynamically changing environment. Nature 454, 1119-1122, doi:10.1038/nature07211 (2008).

26 Hansen, A. S., Hao, N. \& O'Shea, E. K. High-throughput microfluidics to control and measure signaling dynamics in single yeast cells. Nature protocols 10, 1181-1197, doi:10.1038/nprot.2015.079 (2015).

27 Lee, P. J., Helman, N. C., Lim, W. A. \& Hung, P. J. A microfluidic system for dynamic yeast cell imaging. BioTechniques 44, 91-95 (2008).

28 Charvin, G., Cross, F. R. \& Siggia, E. D. A Microfluidic Device for Temporally Controlled Gene Expression and Long-Term Fluorescent Imaging in Unperturbed Dividing Yeast Cells. PloS one 3, e1468, doi:10.1371/journal.pone.0001468 (2008).

29 Fehrmann, S. et al. Aging yeast cells undergo a sharp entry into senescence unrelated to the loss of mitochondrial membrane potential. Cell reports 5, 1589-1599, doi:10.1016/j.celrep.2013.11.013 (2013).

30 Ryley, J. \& Pereira-Smith, O. M. Microfluidics device for single cell gene expression analysis in Saccharomyces cerevisiae. Yeast 23, 1065-1073, doi:10.1002/yea.1412 (2006).

31 Rowat, A. C., Bird, J. C., Agresti, J. J., Rando, O. J. \& Weitz, D. A. Tracking lineages of single cells in lines using a microfluidic device. Proceedings of the National Academy of Sciences 106, 1814918154, doi:10.1073/pnas.0903163106 (2009).

32 Meitinger, F. et al. A Memory System of Negative Polarity Cues Prevents Replicative Aging. Cell 159, 1056-1069, doi:10.1016/j.cell.2014.10.014 (2014).

33 Rafelski, S. M. et al. Mitochondrial Network Size Scaling in Budding Yeast. Science 338, 822-824, doi:10.1126/science.1225720 (2012).

34 Saarikangas, J. \& Barral, Y. Protein aggregates are associated with replicative aging without compromising protein quality control. eLife 4, e06197, doi:10.7554/eLife.06197 (2015).

35 Denoth-Lippuner, A., Krzyzanowski, M. K., Stober, C. \& Barral, Y. Role of SAGA in the asymmetric segregation of DNA circles during yeast ageing. eLife 3, e03790, doi:10.7554/eLife.03790 (2014).

36 Yang, J. et al. Systematic analysis of asymmetric partitioning of yeast proteome between mother and daughter cells reveals "aging factors" and mechanism of lifespan asymmetry. Proceedings of the National Academy of Sciences 112, 11977-11982, doi:10.1073/pnas.1506054112 (2015).

$37 \mathrm{Xie}$, Z. et al. Early Telomerase Inactivation Accelerates Aging Independently of Telomere Length. Cell 160, 928-939, doi:10.1016/j.cell.2015.02.002 (2015). 
McVey, M., Kaeberlein, M., Tissenbaum, H. A. \& Guarente, L. The short life span of Saccharomyces cerevisiae sgs1 and srs2 mutants is a composite of normal aging processes and mitotic arrest due to defective recombination. Genetics 157, 1531-1542 (2001). Delaney, J. R. et al. End-of-life cell cycle arrest contributes to stochasticity of yeast replicative aging. FEMS Yeast Res 13, 267-276, doi:10.1111/1567-1364.12030 (2013).

40 Egilmez, N. K. \& Jazwinski, S. M. Evidence for the involvement of a cytoplasmic factor in the aging of the yeast Saccharomyces cerevisiae. J Bacteriol 171, 37-42 (1989).

$41 \mathrm{Xu}, \mathrm{Z}$. et al. Two routes to senescence revealed by real-time analysis of telomerase-negative single lineages. Nature communications 6, 7680, doi:10.1038/ncomms8680 (2015).

42 Hughes, A. L. \& Gottschling, D. E. An early age increase in vacuolar pH limits mitochondrial function and lifespan in yeast. Nature 492, 261-265, doi:10.1038/nature11654 (2012). Veatch, J. R., McMurray, M. A., Nelson, Z. W. \& Gottschling, D. E. Mitochondrial Dysfunction Leads to Nuclear Genome Instability via an Iron-Sulfur Cluster Defect. Cell 137, 1247-1258, doi:10.1016/j.cell.2009.04.014 (2009).

44 Lai, C.-Y., Jaruga, E., Borghouts, C. \& Jazwinski, S. M. A Mutation in the ATP2 Gene Abrogates the Age Asymmetry Between Mother and Daughter Cells of the Yeast Saccharomyces cerevisiae. Genetics 162, 73-87 (2002).

45 Scheckhuber, C. Q. et al. Reducing mitochondrial fission results in increased life span and fitness of two fungal ageing models. Nature cell biology 9, 99-105, doi:10.1038/ncb1524 (2007). Delaney, J. R. et al. Dietary restriction and mitochondrial function link replicative and chronological aging in Saccharomyces cerevisiae. Exp Gerontol 48, 1006-1013, doi:10.1016/j.exger.2012.12.001 (2013).

47 Kaeberlein, M., Kirkland, K. T., Fields, S. \& Kennedy, B. K. Genes determining yeast replicative life span in a long-lived genetic background. Mech Ageing Dev 126, 491-504, doi:10.1016/j.mad.2004.10.007 (2005).

48 Kennedy, B. K., Austriaco, N. R. \& Guarente, L. Daughter cells of Saccharomyces cerevisiae from old mothers display a reduced life span. The Journal of cell biology 127, 1985-1993, doi:10.1083/jcb.127.6.1985 (1994).

49 Klein, J. P. \& Moeschberger, M. L. Survival Analysis. (Springer-Verlag, 2003).

50 Yang, J. et al. Cell size and growth rate are major determinants of replicative lifespan. Cell Cycle 10, 144-155, doi:10.4161/cc.10.1.14455 (2011).

$51 \mathrm{He}, \mathrm{C}$. et al. Enhanced longevity by ibuprofen, conserved in multiple species, occurs in yeast through inhibition of tryptophan import. PLoS Genet 10, e1004860, doi:10.1371/journal.pgen.1004860 (2014).

52 Huberts, D. H. E. W. et al. Calorie restriction does not elicit a robust extension of replicative lifespan in Saccharomyces cerevisiae. Proceedings of the National Academy of Sciences 111, 11727-11731, doi:10.1073/pnas.1410024111 (2014).

53 Smith, E. D., Kennedy, B. K. \& Kaeberlein, M. Genome-wide identification of conserved longevity genes in yeast and worms. Mech Ageing Dev 128, 106-111, doi:10.1016/j.mad.2006.11.017 (2007).

54 Smith, E. D. et al. Quantitative evidence for conserved longevity pathways between divergent eukaryotic species. Genome Res 18, 564-570, doi:10.1101/gr.074724.107 (2008).

55 Kaeberlein, M., Kirkland, K. T., Fields, S. \& Kennedy, B. K. Sir2-independent life span extension by calorie restriction in yeast. PLOS Bio/ 2, E296, doi:10.1371/journal.pbio.0020296 (2004).

56 Steffen, K. K. et al. Yeast life span extension by depletion of 60 s ribosomal subunits is mediated by Gcn4. Cell 133, 292-302, doi:10.1016/j.cell.2008.02.037 (2008).

57 Dang, W. et al. Histone H4 lysine 16 acetylation regulates cellular lifespan. Nature 459, 802-807, doi:10.1038/nature08085 (2009). 
58 Kaeberlein, M. et al. Regulation of yeast replicative life span by TOR and Sch9 in response to nutrients. Science 310, 1193-1196, doi:10.1126/science.1115535 (2005).

59 Delaney, J. R. et al. Sir2 deletion prevents lifespan extension in 32 long-lived mutants. Aging Cell 10, 1089-1091, doi:10.1111/j.1474-9726.2011.00742.x (2011).

60 Kruegel, U. et al. Elevated proteasome capacity extends replicative lifespan in Saccharomyces cerevisiae. PLoS Genet 7, e1002253, doi:10.1371/journal.pgen.1002253 (2011).

61 Das, S. P. \& Sinha, P. The budding yeast protein Chl1p has a role in transcriptional silencing, rDNA recombination, and aging. Biochem Biophys Res Commun 337, 167-172, doi:10.1016/j.bbrc.2005.09.034 (2005).

62 Managbanag, J. R. et al. Shortest-path network analysis is a useful approach toward identifying genetic determinants of longevity. PLoS One 3, e3802, doi:10.1371/journal.pone.0003802 (2008).

63 Jo, M. C., Liu, W., Gu, L., Dang, W. \& Qin, L. High-throughput analysis of yeast replicative aging using a microfluidic system. Proc Natl Acad Sci U S A 112, 9364-9369,

doi:10.1073/pnas.1510328112 (2015). 


\section{FIGURE LEGENDS}

Figure 1: Microfluidic device designs. A) This device relies both on a shortened confining ceiling, and chemical bonds. The surface of the glass is coated in streptavidin, and all the mother cells are labeled with biotin. This not only confines the cells vertically, but bonds them chemically to the surface. B) Two groups independently developed devices that rely solely on confinement under small columns or micropads. These small regions physically restrain the larger mothers, but allow the newborn daughters to wash away. C) CLiC device. This constrains the cells in both the vertical dimension, and places the mother cell in a narrow, elongated cavity in the wall. A small confluent monolayer of cells grows around the cavity, but once the region is full, cells are pushed out and washed away by the bypass channels. D) ALCATRAS device design. A small set of PDMS pillars in a V-shape traps the larger mother cells, and allow daughters to bud through the opening and be washed away. E) HYAA device design. A pair of L-shaped PDMS pillars traps mother cells and allows daughters to be removed by flow. F) Yeast Replicator device design. A small PDMS jail composed of three square pillars traps small newborn daughters and holds them. New daughters bud outside the trap and are washed away. 
Table 1: Key differences between microfluidic devices. *Actual number of trapped mother cells/field of view is highly dependent on loading protocol including density of seeding culture, injection pressure, and length of seeding period. Often, optimal filling of traps must be balanced against having too many cells per trap or a greater chance of cells caught in non-trap areas leading to overgrowth of device.

\begin{tabular}{|c|c|c|c|c|c|c|c|c|}
\hline $\begin{array}{l}\text { Publications } \\
\text { Grouped by } \\
\text { Device }\end{array}$ & $\begin{array}{l}\text { Trapping } \\
\text { Method }\end{array}$ & $\begin{array}{l}\text { Strains } \\
\text { per } \\
\text { Device }\end{array}$ & $\begin{array}{l}\text { Mother } \\
\text { Retention }\end{array}$ & $\begin{array}{l}\text { Ensure } \\
\text { Virgins }\end{array}$ & $\begin{array}{l}\text { Single Trap } \\
\text { Footprint* }\end{array}$ & \multicolumn{2}{|c|}{$\begin{array}{l}\text { Mutant Strains Tested for } \\
\text { Lifespan }\end{array}$} & $\begin{array}{l}\text { Raw } \\
\text { Data } \\
\text { Provided }\end{array}$ \\
\hline $\begin{array}{l}\text { Xie et al. } 2012 \\
\text { Rafelski et al. } \\
2012\end{array}$ & $\begin{array}{l}\text { Height } \\
\text { restriction } \\
+ \\
\text { Chemical }\end{array}$ & 8 & $\begin{array}{l}\text { Not } \\
\text { Reported }\end{array}$ & No & $\begin{array}{l}\text { N/A, "3-5 cells } \\
\text { per field of } \\
\text { view" }\end{array}$ & \multicolumn{2}{|l|}{ 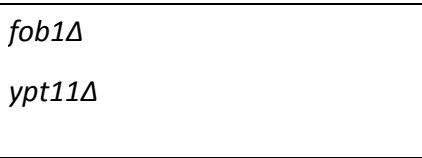 } & $\begin{array}{l}\text { Videos of } \\
\text { entire } \\
\text { field of } \\
\text { view }\end{array}$ \\
\hline $\begin{array}{l}\text { Lee et al. } \\
2012 \\
\text { Huberts et al. } \\
2014\end{array}$ & $\begin{array}{l}\text { Pensile } \\
\text { Column/ } \\
\text { Micropad }\end{array}$ & 1 & 15-30\% & No & $\begin{array}{l}\text { Single pad: } \\
450 \mu \mathrm{m}^{2} \\
\text { With spacing: } \\
\sim 850 \mu \mathrm{m}^{2} \\
\text { (up to } 2 \\
\text { cells/trap) }\end{array}$ & \multicolumn{2}{|l|}{$\begin{array}{l}\text { fob1 } \\
\operatorname{sir} 2 \Delta\end{array}$} & $\begin{array}{l}\text { Videos of } \\
\text { single } \\
\text { traps }\end{array}$ \\
\hline $\begin{array}{l}\text { Zhang et al. } \\
2012 \\
\text { Xie et al. } 2015\end{array}$ & $\begin{array}{l}\text { Pensile } \\
\text { Column/ } \\
\text { Micropad }\end{array}$ & 4 & $\begin{array}{l}\text { Not } \\
\text { Reported }\end{array}$ & No & $\begin{array}{l}\text { Single column: } \\
1600 \mu \mathrm{m}^{2} \\
\text { Spacing not } \\
\text { reported } \\
\text { (up to } 2 \\
\text { cells/trap) }\end{array}$ & \multicolumn{2}{|c|}{ 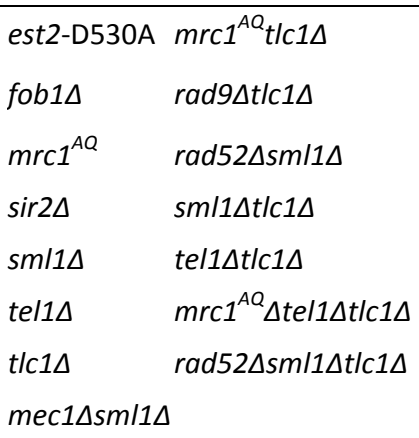 } & $\begin{array}{l}\text { Videos of } \\
\text { single } \\
\text { traps }\end{array}$ \\
\hline $\begin{array}{l}\text { Fehrmann et } \\
\text { al. } 2013 \\
\text { Meitinger et } \\
\text { al. } 2014\end{array}$ & $\begin{array}{l}\text { Elongated } \\
\text { Cavities }\end{array}$ & 1 & $\sim 65 \%$ & Yes & $\begin{array}{l}\text { Single } \\
\text { trapping area: } \\
\sim 3840 \mu \mathrm{m}^{2} \\
\text { (up to } 2 \\
\text { cells/trapping } \\
\text { area) }\end{array}$ & \multicolumn{2}{|c|}{ 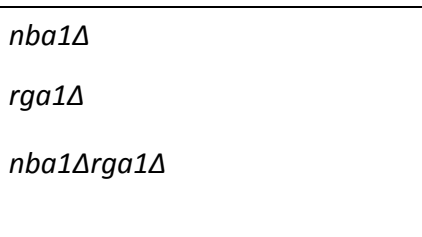 } & $\begin{array}{l}\text { Videos of } \\
\text { single } \\
\text { traps }\end{array}$ \\
\hline $\begin{array}{l}\text { Crane et al. } \\
2014\end{array}$ & $\begin{array}{l}\text { 2-Column } \\
\text { Traps }\end{array}$ & 1 & $\sim 40-60 \%$ & No & $\begin{array}{l}\text { Single trap: } \\
\sim 100 \mu \mathrm{m}^{2} \\
\text { With spacing: } \\
\sim 750 \mu \mathrm{m}^{2}\end{array}$ & \multicolumn{2}{|l|}{ None } & $\begin{array}{l}\text { Video of } \\
\text { entire } \\
\text { chip }\end{array}$ \\
\hline Jo et al. 2015 & $\begin{array}{l}\text { 2-Column } \\
\text { Traps }\end{array}$ & 16 & $>90 \%$ & No & $\begin{array}{l}\text { Single trap: } \\
\sim 200 \mu \mathrm{m}^{2} \\
\text { With spacing; } \\
\sim 700 \mu \mathrm{m}^{2}\end{array}$ & 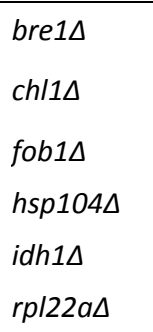 & 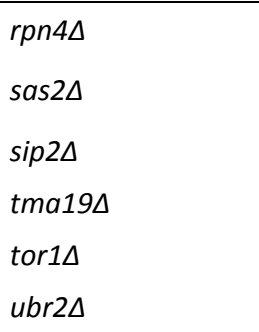 & $\begin{array}{l}\text { Videos of } \\
\text { single } \\
\text { traps }\end{array}$ \\
\hline Liu et al. 2015 & $\begin{array}{l}\text { 3-Column } \\
\text { Jails }\end{array}$ & 10 & $\begin{array}{l}\text { Not } \\
\text { Reported }\end{array}$ & Yes & $\begin{array}{l}\text { Single trap: } \\
\sim 175 \mu \mathrm{m}^{2} \\
\text { With spacing: } \\
1788 \mu \mathrm{m}^{2}\end{array}$ & 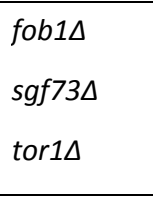 & 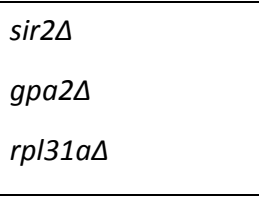 & $\begin{array}{l}\text { Photos } \\
\text { of single } \\
\text { cells of } \\
\text { unknown } \\
\text { age }\end{array}$ \\
\hline
\end{tabular}



Table 2: Reported lifespans of wild-type haploid cells in each microfluidic device. *Approximate values are estimated from survival curves. ${ }^{+}$Includes all details specified in the publication

\begin{tabular}{|c|c|c|c|c|c|}
\hline $\begin{array}{l}\text { Reporting } \\
\text { Publication }\end{array}$ & $\begin{array}{l}\text { Trapping } \\
\text { Principle }\end{array}$ & $\begin{array}{l}\text { Running } \\
\text { Media }\end{array}$ & $\begin{array}{l}\text { Growth Conditions Prior to } \\
\text { Loading }^{+}\end{array}$ & Strain & Lifespan* \\
\hline Xie et al. 2012 & $\begin{array}{l}\text { Mechanical + } \\
\text { Chemical }\end{array}$ & YPD & grown in YPD & BY4741 & median $\approx 17$ \\
\hline $\begin{array}{l}\text { Lee et al. } \\
2012\end{array}$ & $\begin{array}{l}\text { Pensile } \\
\text { Column/ } \\
\text { Micropad }\end{array}$ & $\begin{array}{l}\text { YPD or Synthetic } \\
\text { Defined with } 2 \% \\
\text { glucose }\end{array}$ & $\begin{array}{l}\text { grown overnight to stationary } \\
\text { phase, diluted to } \mathrm{OD}_{600}=0.3 \text {, } \\
\text { incubated } 3 \text { h at } 30^{\circ} \mathrm{C} \text {, } \\
\text { sonicated mildly }\end{array}$ & "BY" & median $=25$ \\
\hline $\begin{array}{l}\text { Zhang et al. } \\
2012\end{array}$ & $\begin{array}{l}\text { Pensile } \\
\text { Column/ } \\
\text { Micropad }\end{array}$ & Not Reported & $\begin{array}{l}\text { grown in YPED at } 30^{\circ} \mathrm{C} \\
\text { overnight to } \mathrm{OD}_{600}=1.0, \\
\text { diluted } 1: 50, \text { incubated } 6 \mathrm{~h} \\
\text { at } 30^{\circ} \mathrm{C}\end{array}$ & $\begin{array}{l}\text { BY4741 } \\
\text { BY4742 }\end{array}$ & $\begin{array}{l}\text { BY4741: } \text { mean }=23.6 \\
\text { BY4742: } \text { mean }=26.0\end{array}$ \\
\hline $\begin{array}{l}\text { Fehrmann et } \\
\text { al. } 2013\end{array}$ & $\begin{array}{l}\text { Elongated } \\
\text { Cavities }\end{array}$ & $\begin{array}{l}\text { Synthetic } \\
\text { Complete with } \\
2 \% \text { glucose (SC) }\end{array}$ & $\begin{array}{l}\text { "... grown overnight, } \\
\text { transferred to fresh medium } \\
\text { the next morning, and } \\
\text { allowed to grow to log phase } \\
\text { until transfer to the } \\
\text { microfluidic device in the } \\
\text { afternoon." }\end{array}$ & BY4741 & $\begin{array}{l}\text { Including right- } \\
\text { censored cells: } \\
\text { median = } 32.4 \\
\text { Including only cells } \\
\text { seen to die: } \\
\text { median }=25.3\end{array}$ \\
\hline $\begin{array}{l}\text { Crane et al. } \\
2014\end{array}$ & $\begin{array}{l}\text { 2-Column } \\
\text { Traps }\end{array}$ & $\begin{array}{l}\mathrm{XY} \text { with } 2 \% \\
\text { glucose }\end{array}$ & $\begin{array}{l}\text { grown overnight in } \mathrm{XY} \text { with } \\
2 \% \text { glucose "and then diluted } \\
\text { and allowed to grow to log } \\
\text { phase..." }\end{array}$ & S288C & mean $=22.4$ \\
\hline Jo et al. 2015 & $\begin{array}{l}\text { 2-Column } \\
\text { Traps }\end{array}$ & $\begin{array}{l}\text { YPD, } \\
\text { Synthetic } \\
\text { Complete with } \\
2 \% \text { glucose (SC) }\end{array}$ & $\begin{array}{l}\text { "... cultured in YPD at } \\
30^{\circ} \mathrm{C} \text { overnight before } \\
\text { diluting } 10-50 \text {-fold and } \\
\text { loading..." }\end{array}$ & BY4741 & $\begin{array}{l}\text { YPD: } \text { mean }=26.76 \\
\text { SC: } \text { mean }=24.16\end{array}$ \\
\hline Liu et al. 2015 & $\begin{array}{l}\text { 3-Column } \\
\text { Jails }\end{array}$ & $\begin{array}{l}\text { YPD, } \\
\text { CSM with } 2 \% \\
\text { glucose }\end{array}$ & $\begin{array}{l}\text { grown overnight in CSM with } \\
2 \% \text { glucose to final density of } \\
0.25\end{array}$ & "BY" & $\begin{array}{l}\text { YPD: } \text { mean = } 22.2 \\
\text { CSM: } \text { mean = } 24.2\end{array}$ \\
\hline
\end{tabular}


Table 3: Reported lifespans for various haploid strains in the S288C/BY background measured in microfluidic devices. Microfluidic lifespan values to the tenth precision indicate mean. Whole number indicates median. Tilde indicates median estimated from survival curve. Microdissection lifespan ranges are reported as mean and were obtained from published studies in the BY4742 strain background ${ }^{6,47,54-}$ 63.

\begin{tabular}{|c|c|c|}
\hline Strain & Microfluidic Lifespan & Microdissection Lifespan \\
\hline bre1s & 17.2 (Jo et al. 2015) & 17.6 \\
\hline ch/1 & 19.3 (Jo et al. 2015) & 16.0 \\
\hline est2-D530A & 7.6 (Zhang et al. 2015) & \\
\hline fob1 $\Delta$ & $\begin{array}{l}29 \text { (Xie et al. 2012) } \\
33.1 \text { (Zhang et al. 2012) } \\
33.9 \text { (Jo et al. 2015) } \\
31.0 \text { (Liu et al. 2015) }\end{array}$ & $27.4-37.8$ \\
\hline gpa2s & 29.9 (Liu et al. 2015) & $32.0-36.7$ \\
\hline hsp104A & 26.0 (Jo et al. 2015) & 32.4 \\
\hline idh1 & 27.9 (Jo et al. 2015) & $30.5-33.5$ \\
\hline$m r c 1^{A Q}$ & $\sim 25$ (Zhang et al. 2015) & \\
\hline$n b a 1 \Delta$ & 14 (Meitinger et al. 2014) & \\
\hline rga1s & 12 (Metinger et al. 2014) & \\
\hline$r p / 22 a \Delta$ & 30.0 (Jo et al. 2015) & $35.8-39.8$ \\
\hline$r p / 31 a \Delta$ & 30.6 (Liu et al. 2015) & $34.6-35.5$ \\
\hline$r p n 4 \Delta$ & 18.1 (Jo et al. 2015) & $13.3-17.3$ \\
\hline $\operatorname{sas} 2 \Delta$ & 31.8 (Jo et al. 2015) & $28.4-32.4$ \\
\hline 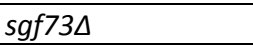 & 29.6 (Liu et al. 2015) & 42.2 \\
\hline $\operatorname{sip} 2 \Delta$ & 28.6 (Jo et al. 2015) & 31.1 \\
\hline $\operatorname{sir} 2 \Delta$ & $\begin{array}{l}15.4 \text { (Zhang et al. 2012) } \\
13.3 \text { (Jo et al. 2015) } \\
12.7 \text { (Liu et al. 2015) }\end{array}$ & $12.4-14.0$ \\
\hline$s m / 1 \Delta$ & 〜27 (Zhang et al. 2015) & \\
\hline tel1 $\Delta$ & 27 (Zhange et al. 2015) & \\
\hline$t / c 1 \Delta$ & 12.6 (Zhang et al. 2015) & \\
\hline tma194 & 27.3 (Jo et al. 2015) & 33.4 \\
\hline $\operatorname{tor} 1 \Delta$ & $\begin{array}{l}29.0 \text { (Jo et al. 2015) } \\
30.7 \text { (Liu et al. 2015) }\end{array}$ & $28.1-33.2$ \\
\hline$u b r 2 \Delta$ & 31.2 (Jo et al. 2015) & $35.9-42.5$ \\
\hline ypt11ム & $\begin{array}{l}\text { Bimodal, overall mean unspecified } \\
\text { (Rafelski et al. 2012) }\end{array}$ & \\
\hline$m e c 1 \Delta s m / 1 \Delta$ & 20 (Zhang et al. 2015) & \\
\hline$m r c 1^{A Q} t / c 1 \Delta$ & 8.8 (Zhang et al. 2015) & \\
\hline$n b a 1 \Delta r g a 1 \Delta$ & 6 (Meitinger et al. 2014) & \\
\hline rad9 $\Delta t / c 1 \Delta$ & 16.5 (Zhang et al. 2015) & \\
\hline $\operatorname{rad} 52 \Delta s m / 1 \Delta$ & 12 (Zhang et al. 2015) & \\
\hline$s m / 1 \Delta t / c 1 \Delta$ & 〜22 (Zhang et al. 2015) & \\
\hline tel1 $\Delta t / c 1 \Delta$ & 9.8 (Zhang et al. 2015) & \\
\hline$m r c 1^{A Q} \Delta t e l 1 \Delta t / c 1 \Delta$ & 11.5 (Zhang et al. 2015) & \\
\hline 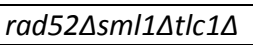 & $\sim 7$ (Zhang et al. 2015) & \\
\hline
\end{tabular}

